\title{
The effects of maternal age and parity on birth weight in a tribal community of Kinwat, Nanded, Maharashtra, India
}

\author{
Ramdas G. Narwade ${ }^{1 *}$, Uttam B. More ${ }^{2}$
}

\begin{abstract}
${ }^{1}$ Department of Obstetrics and Gynecology, IIMSR Medical College, Badnapur, Jalna, Maharashtra, India
${ }^{2}$ Department of Obstetrics and Gynecology, More Nursing Home, Kinwat, Nanded, Maharashtra, India
\end{abstract}

Received: 18 August 2018

Accepted: 20 September 2018

\section{*Correspondence:}

Dr. Ramdas G. Narwade,

E-mail: shrutinarwde4@gmail.com

Copyright: () the author(s), publisher and licensee Medip Academy. This is an open-access article distributed under the terms of the Creative Commons Attribution Non-Commercial License, which permits unrestricted non-commercial use, distribution, and reproduction in any medium, provided the original work is properly cited.

\begin{abstract}
Background: Low birth weight is an important determinant of childhood morbidity and mortality. Birth weight is a significant factor that determines vulnerability of risk of childhood illness and survival. Objective of the study was to correlate the maternal age and parity on birth weight in a tribal community.

Methods: A cross-sectional study was carried out during April 2012 to June 2014 in More Nursing Home, Kinwat Dist. Nanded, Maharashtra. A total of 1611 patients from tribal area who delivered in the nursing home were enclosed for the study. Data was analyzed by using SSPS version-18.0.

Results: In this study low birth weight babies were seen in $18.56 \%$ and $17.78 \%$ and $21.47 \%$ of female and male babies had low birth weight respectively, which was statistically significant. Mean birth weight increased as parity of mother increased. Low birth weight babies were born to the mother of younger age which was statistically significant. Conclusions: Health care of young age tribal mothers is important factor in curbing low birth weight babies.
\end{abstract}

Keywords: Birth weight, Maternal age, Parity, Tribal community

\section{INTRODUCTION}

Birth weight is a major determinant of child's health and nutrition. The incidence of low birth weight defined as the proportion of new births less than 2500 gm minored thought health system surveillance and house hold surveys. ${ }^{1}$ In 2013, as many as 22 million born as estimated $16 \%$ babies born globally has LBW according to the UNICEF. Being undernourished in the womb increases the risk of death in the early months and years of child's life. Those who survive tend to have impairing immune function and risk of disease. They are likely to remain undernourished with reduced muscle strength, cognitive utilities and IQ throughout their lives. As adults, they suffer a higher incidence of diabetes and heart disease. ${ }^{2}$ In India, birth weight has remained low with NFHS reported proportion of low birth weight
(LBW) babies of $22.7 \%$ for rural and $19 \%$ for urban population. ${ }^{3}$ The reported birth rate in the state of Maharashtra is 19 per 1000 population per year. ${ }^{4}$ And its neonatal mortality rate in 32 per 1000 live birth a year. ${ }^{5}$

The main cause of neonatal mortality is LBW followed by sepsis and respiratory illness. ${ }^{6}$ About $80 \%$ of the tribals in India live in remote forest areas and hilly regions, without an access to the modern socioeconomic inputs. Current status of tribal population, as reported in 2011 census is $8.63 \%$ of nation total population, whereas tribal population of Maharashtra is 8.6 million. The district of Nanded in central state of Maharashtra has nearly $8.8 \%$ tribal population. ${ }^{7}$

The death of every other new born in India can be traced to either low birth weight or premature delivery a 
reflection of poor maternal health and an inadequate health care system according to an India Spend Analysis of census data. Kinwat tribal contribute to $29 \%$ of total population of Kinwat Taluka of 2, 47,786 with female literacy rate of $55.45 \%$ and male literacy rate of $72.8 \%{ }^{8}$ Tribal communities have inequalities in health care due the distances that they have to travel.

India's policy makers and health workers have recognized that saving the lives of newborn babies does not require enormous resources or complicated expertise. ${ }^{9}$ One of the biggest challenges in implementing any strategy across communities in India is to reach them, especially tribal areas with poor infrastructure, lack of human resources and deferent cultural norms. There is little known about the natural history of pregnancies and neonates born in tribal areas in India. ${ }^{10}$ Hence the present study was conducted to know the effects of maternal age and parity on birth weight babies in a tribal community of Kinwat, Nanded district of Maharashtra.

\section{METHODS}

A cross-sectional study was carried out in More Nursing Home, Kinwat, District Nanded, Maharashtra, India during the period of April 2012 to June 2014. Study population was predominantly inhibited by tribal communities' women who delivered in More Hospital who fulfilled inclusion and exclusion criteria. The total 1611 women who delivered in More Hospital and fulfilled the inclusion and exclusion criteria were enrolled for the study. Hence the sample size was 1611. Key variable measures on the mothers and households included socio-economic characteristics like education, age, parity, weight and birth weight were recorded.

\section{Inclusion criteria}

Term delivery without any medical disorders like preeclampsia, gestational diabetes, anemia, IUGR, cardiac disorders, thyroid dysfunction etc.

\section{Exclusion criteria}

Patients with preterm delivery were excluded from the study.

\section{Statistical analysis}

The data was analyzed by computer software MS Excel and statistical package for the social science SPSS version 18.0.

\section{RESULTS}

It was seen from Table 1 that the incidence of low birth weight (LBW) babies of 299(18.56\%) amongst 1611 deliveries and of them $1312(81.44 \%)$ of babies had weight equal or more than $2.5 \mathrm{~kg}$. Incidence of low birth weight babies is contributing $18.56 \%$ in this study.
Table 1: Distribution babies according to birth weight.

\begin{tabular}{|lll|}
\hline Birth weight & Frequency & Percentage \\
\hline$<2.5 \mathrm{~kg}$ & 299 & 18.56 \\
\hline$\geq 2.5 \mathrm{~kg}$ & 1312 & 81.44 \\
\hline Total & 1611 & 100 \\
\hline
\end{tabular}

It was observed from Table 2 that $130(15.78 \%)$ male and $169(21.47 \%)$ female babies had low birth weight respectively and which was also statically significant. There were $694(84.22 \%)$ male and $618(78.53 \%)$ female babies had weight equal or more than $2.5 \mathrm{~kg}$.

Table 2: Distribution of birth weight according to gender.

\begin{tabular}{|c|c|c|c|c|}
\hline \multirow{2}{*}{$\begin{array}{l}\text { Birth } \\
\text { weight }\end{array}$} & \multicolumn{2}{|c|}{ Gender } & \multirow{2}{*}{$\begin{array}{l}\chi^{2}- \\
\text { value }\end{array}$} & \multirow{2}{*}{$\begin{array}{l}\text { p- } \\
\text { value }\end{array}$} \\
\hline & Male No. (\%) & Female No. (\%) & & \\
\hline$<2.5 \mathrm{~kg}$ & $130(15.78)$ & $169(21.47)$ & \multirow{3}{*}{8.44} & \multirow{3}{*}{$\begin{array}{l}0.003 \\
\text { HS }\end{array}$} \\
\hline$\geq 2.5 \mathrm{~kg}$ & $694(84.22)$ & $618(78.53)$ & & \\
\hline Total & $824(100)$ & $787(100)$ & & \\
\hline
\end{tabular}

It was observed from Table 3 that mean birth weight of $2.67 \mathrm{~kg}, 2.79 \mathrm{~kg}, 2.82 \mathrm{~kg}, 2.86 \mathrm{~kg}$ and $2.95 \mathrm{~kg}$ in mothers of parity 1 , parity 2 , parity 3 , parity 4 and parity 5 or more than 5 and these results were highly significant.

Table 3: Distribution of mean birth weight according to parity of mothers.

\begin{tabular}{|llllll|} 
Parity & No. & $\begin{array}{l}\text { Mean birth } \\
\text { weight }\end{array}$ & SD & $\chi^{2}$-value & p-value \\
\cline { 1 - 3 } 1 & 877 & 2.6761 & 0.5028 & & \\
\hline 2 & 511 & 2.7964 & 0.4837 & & \\
\cline { 1 - 3 } 3 & 156 & 2.8205 & 0.5647 & & 0.000 \\
\hline 4 & 43 & 2.8651 & 0.5270 & & HS \\
\cline { 1 - 2 } & 24 & 2.9500 & 0.3581 & & \\
\hline
\end{tabular}

It was seen from Table 4 that as the age of mother increased mean birth weight also increased. Mean birth weight was $2.61 \mathrm{~kg}$ in mother's age of less than 20 years, $2.78 \mathrm{~kg}$ in mother of 25 to 29 years age group and 2.92 $\mathrm{kg}$ in mothers of 35 years and above and these results were highly significant.

Table 4: Association of mean birth weight according to age of mother.

\begin{tabular}{|c|c|c|c|c|c|}
\hline $\begin{array}{l}\text { Age of } \\
\text { mothers }\end{array}$ & $\begin{array}{l}\text { Total } \\
\text { births }\end{array}$ & $\begin{array}{l}\text { Mean birth } \\
\text { weight }\end{array}$ & SD & $\begin{array}{l}\chi^{2}- \\
\text { value }\end{array}$ & $\begin{array}{l}\mathrm{p}- \\
\text { value }\end{array}$ \\
\hline $\begin{array}{l}<20 \\
\text { years }\end{array}$ & 75 & 2.6169 & 0.6093 & \multirow{5}{*}{3.52} & \multirow{5}{*}{$\begin{array}{l}0.007 \\
\text { HS }\end{array}$} \\
\hline $\begin{array}{l}20-24 \\
\text { years }\end{array}$ & 994 & 2.7150 & 0.4967 & & \\
\hline $\begin{array}{l}25-29 \\
\text { years }\end{array}$ & 446 & 2.7834 & 0.5018 & & \\
\hline $\begin{array}{l}30-34 \\
\text { years }\end{array}$ & 85 & 2.8259 & 0.5028 & & \\
\hline $\begin{array}{l}\geq 35 \\
\text { years }\end{array}$ & 11 & 2.927 & 0.454 & & \\
\hline
\end{tabular}




\section{DISCUSSION}

In present study, low birth weight was seen in $18.56 \%$ which was comparable to study by Ashtekar SV et al with the percentage of $18.99 \%$ in $1994,17.34 \%$ in 1997 , $19.35 \%$ in 1997 and pooled $24.22 \%$ from $1989-2007 .{ }^{10}$ Similarly study done by Manzur K et al which showed that low birth weight in babies were 20\%. ${ }^{11}$ Another study done by Mondal B showed that high incidence of low birth weight about $28.48 \% .^{12}$ A study conducted by Beakgard ES showed that overall birth weights amongst the tribal population in the area had improved over the past 10 years. ${ }^{13}$ In present study, $21.47 \%$ of female babies were low birth weight which was more when compared to $15.78 \%$ of male babies. Similarly, study done by Mathai $\mathrm{M}$ et al revealed that female infants were on the average 113 gm lighter than male infants. ${ }^{14}$ Present study results were similar with Bharati $\mathrm{P}$ et al and Mondal $\mathrm{B}$ study. ${ }^{12,15}$ Another study done by Ashtekar SV et al which showed no gender difference in the average birth weight. ${ }^{10}$ Present study showed that, as the parity increased birth weight also increased, comparable to the study by Mathai $\mathrm{M}$ et al. ${ }^{14}$ Later born babies were on the average $130 \mathrm{gm}(95 \% \mathrm{CI} 40-220 \mathrm{~g})$ heavier than first born babies. Another study done by Ashtekar SV et al found that the ordered of birth did not make no difference in the study..$^{10} \mathrm{~A}$ study by Mondal B also showed high incidence of low birth weight in $5+$ parity. ${ }^{12}$ The present study showed that as the age of mother increased, mean birth weight also increased from $2.62 \mathrm{~kg}$ to $2.93 \mathrm{~kg}$ in mothers of $<20$ years to $>35$ years of age, this was similar to the study by Ashtekar SV et al. ${ }^{10}$ The average birth weight does not change across different age groups of mother. Birth weight was also not significantly different between age groups, mothers below (birth weight 2.71 $\mathrm{kg}$ ) and above 21 years (birth weight $2.72 \mathrm{~kg}$ ). There is no difference in mean birth weight of babies of mothers below or above 18 years of age $(\mathrm{p}=0.86)$. The correlation coefficient between age of a mother and birth weight of baby was weak though statically significant. A study by Mondal B showed that there was no effect of age of the mother and the low birth weight. ${ }^{12}$

\section{CONCLUSION}

Study concluded that as the age of mother increased, mean birth weight also increased. As the parity increased birth weight also increased. The average birth weight does not change across different age groups of mother. Health care of young age tribal mothers is important factor in curbing low birth weight babies.

Funding: No funding sources Conflict of interest: None declared

Ethical approval: The study was approved by the Institutional Ethics Committee

\section{REFERENCES}

1. Low birth weight. Available at: UNICEF/data.unicef.org.

2. National family health survey NFHS-2 IIPS state finding 1998-99. Available at: https://dhsprogram.com/pubs/pdf/sr81/sr81.pdf.

3. Government of India 2005. Sample Registration System. Available at: http://www.censusindia.gov.in/Vital_Statistics/SRS/Sa mple_Registration_System.aspx.

4. Research projects: National Family Health Survey --2. IIPS Newsl. 1999;40:2-4. Available at: https://www.ncbi.nlm.nih.gov/pubmed/12295443.

5. Niswade A, Zodpey SP, Ughade S, Bangdiwala SI. Neonatal morbidity and mortality in tribal and rural communities in central India. Indian $\mathrm{J}$ Comm Med: Official Pub Indian Assoc Prev Soc Med. 2011;36(2):150-8.

6. World health population, 2006. Available at: www.shodhganga.inflibnet.ac.in/bistream10603/99868/ $10 / 10$.

7. Kinwat Taluka population, caste, religion data- Nanded district of Maharashtra. Available at: https//www/censusindia.co.in

8. Kumar V, Mohanty S, Kumar A, Misra RP, Santosham M, Awasthi S, et al. Effect of community-based behaviour change management on neonatal mortality in Shivgarh, Uttar Pradesh, India: A cluster-randomised controlled trial. Lancet. 2008;372:1151-62.

9. Bang AT, Reddy HM, Baitule SB, Desmukh MD, Band RA. The incidence of morbidities in a cohort of neonates in rural Gadchiroli, India: Seasonal and temporal variation and a hypothesis about prevention. $\mathrm{J}$ Perinatol. 2005;25:S18-28.

10. Ashtekar SV, Kulkarni MB, Sadavarte VS, Ashtekar RS. Analysis of Birth weight of rural hospital. Indian J. Community Med. 2010;35(2):252-5.

11. Kader M, Perera NK. Socioeconomic and nutritional determinants of low birth weight in India. N Am J Med Sci. 2014;6(7):302-8.

12. Mondal B. Low birth weight in relation to sex of baby, maternal age and parity: a hospital based study on Tangsa tribe from Arunachal Pradesh. J Indian Med Assoc. 1998;96(12):362-4.

13. Baekgard ES, Hulse CL. Trends in birth weight among four tribal communicates in rural Tamil Nadu, India. Rural Remote Health. 2014;14:27-8.

14. Mathai M, Jacob S, Karthikeyan NG. Birth weight standards for south Indian babies. Indian Pediatr. 1996;33(3):203-9.

15. Bharati P, Pal M, Bandyopadhyay M, Bhakta A, Chakraborty S, Bharati P. Prevalence and causes of low birth weight in India. Malays J Nutr. 2011;17(3):30113.

Cite this article as: Narwade RG, More UB. The effects of maternal age and parity on birth weight in a tribal community of Kinwat, Nanded, Maharashtra, India. Int J Reprod Contracept Obstet Gynecol 2018;7:4451-3. 